\title{
Effects of organic acids or natural plant extracts added to diets for turkeys on growth performance, gastrointestinal tract metabolism and carcass characteristics
}

\author{
D. Mikulski ${ }^{1,3}$, Z. Zduńczyk ${ }^{2}$, J. Jankowski ${ }^{1}$ and J. Juśkiewicz ${ }^{2}$ \\ ${ }^{1}$ Warmia and Mazury University, Department of Poultry Science \\ Oczapowskiego 5, 10-718 Olsztyn \\ ${ }^{2}$ Institute of Animal Reproduction and Food Research, \\ Polish Academy of Sciences \\ Tuwima 10, 10-747 Olsztyn, Poland
}

(Received 27 December 2007; revised version 1 February 2008; accepted 8 April 2008)

\begin{abstract}
A study on male turkeys was conducted to evaluate the physiological and growth effects of organic acids, organic acids with essential oils or herbal extract added to diets. The control diet (C) contained premix without any feed additives. Three experimental diets were fed from 1 to 140 days of age: diet A with a blend of organic acids (formic acid and propionic acid) in the amount of $5.0 \mathrm{~g} / \mathrm{kg}$ of feed, diet $\mathrm{AO}$ with a blend of organic acids (citric, fumaric, orthophosphoric and malic acid) and with a mixture of essential oils (from citrus fruits, cinnamon, oregano and thyme) in the amount of 0.5 to $1.0 \mathrm{~g} / \mathrm{kg}$ of feed, diet HE with preparation composed of oregano essential oil, spice extracts of turmeric and capsicum in the amount $0.3 \mathrm{~g} / \mathrm{kg}$ of feed. Gastrointestinal tract development and metabolism (after 56 days of feeding) as well as growth performance and carcass characteristics (after 140 days of the experiment) were evaluated. Dietary supplementation with A, AO or HE significantly decreased the $\mathrm{pH}$ of the crop contents, but had no effect on the $\mathrm{pH}$ of the caecal digesta. Dietary supplementation with A or HE increased the activity of $\alpha$-glucosidase in the ileal digesta. The tested supplements had no influence on SCFA production in the caeca. All supplements increased the body weights of turkeys, but the differences were significant $(\mathrm{P} \leq 0.01)$ only at the age of 84 days. The final body weight (at 140 days of age) of turkeys fed diets with the tested supplements were higher by $3.3-3.9 \%$, and feed conversion ratio decreased by $2.4-5.3 \%$ (statistically non-significantly) in these treatments, compared to the control. Generally, carcass traits were not influenced by the above feed supplements.
\end{abstract}

KEY WORDS: organic acid, herbal extract, performance, gastrointestinal tract, metabolism, turkeys

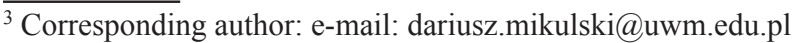




\section{INTRODUCTION}

Organic acids, known to have strong antibacterial effects, are used for feed protection against microbes and fungi (Izat et al., 1990; Chaveerach et al., 2004; Immerseel et al., 2005). Acidifiers are used as salmonella-control agents in feed and water supplied to livestock and poultry. The addition of organic acids to animal feed has been reported to decrease the intraluminal concentration of coliform bacteria and other acid-intolerant organisms, such as Campylobacter and Salmonella, known to be involved in digestive disorders (Canibe et al., 2001). A propionic acidbased product at $1.25 \%$ was quite effective in alleviating turkey poult enteritis and mortality syndrome (Roy et al., 2002).

However, professional literature indicates that the in vivo effects of different organic acids on intestinal bacteria vary a lot and depend on their chemical form and type of microorganisms, animal species, site and location in the gastrointestinal tract and buffering capacity of the feed. The effect of organic acids on broiler performance is dependent upon the dose and type of acid products, as well as on the fact whether the acids are included in feed or drinking water (Patten and Waldroup, 1988).

For many years, herbs and spices and their essential oils have been used as pharmaceuticals in natural therapy. In recent time, aromatic plants and their extracts have been used in animal feeding. Active substances naturally occurring in different plants, particularly in herbs used in human nutrition, have received increasing attention as possible AGP replacements (Nevas et al., 2004). Herbs, parts of herb plants or herbal plant extracts can beneficially affect feed intake, secretion of digestive juices and the immune system of animals.

It is known that most of their properties are due to the essential oils they contain as products of their secondary metabolism (Adam et al., 1998). The essential oil derived from thyme and oregano (carvacrol and thymol) is known to possess in vitro antimicrobial, antifungal and antioxidant activities (Faleiro et al., 2005; Hazzit et al., 2006). Recent studies on experimental animals have revealed that some ingredients of popular herbs and spice plants, e.g., capsaicin or curcumin, can also stimulate digestive enzymes, bile flow and enhance bile acid secretion (Platel and Srinivasan, 2001).

Due to its in vitro antimicrobial activity, oregano essential oil may be expected to have prophylactic and therapeutic effects. Thus, oregano herb or essential oil or sole constituents of oregano essential oil have been tested as growth promoters in chickens and turkeys (Jamroz et al., 2003; Lee et al., 2003; Bampidis et al., 2005; Westendarp et al., 2006). However, the benefits of oregano for animal performance have not been consistent among these studies.

Only scant information is available on commercial herb extracts, bioactive essential oils or organic acids as feed additives in turkey diet. Therefore, the aim 
of this study was to examine the effect of wheat/maize-based diet supplementation with organic acids or natural plant extract on the gastrointestinal tract development, metabolism, performance and carcass characteristic of growing turkeys. Insomuch as the main action of feed additives is associated with the large bowel, special attention was paid to intestinal and caecal parameters (e.g., the activity of microbial enzymes and SCFAs).

\section{MATERIAL AND METHODS}

\section{Animals and diets}

The experiment was conducted according to the guidelines of the Local Animal Experimentation Ethics Committee.

A total of 400 one-day-old heavy Large White BIG-6 turkey males, sexed at the local commercial hatchery were randomly assigned to four dietary treatments, each of four replications. The initial body weight of day-old poults was $61 \mathrm{~g}$. Turkeys had free access to a diet without any of feed antibiotics but Clinacox ${ }^{\mathrm{TM}}$ (Diclazuril) as coccidiostat was used to 84 days of age.

The control diet (C) contained premix without any feed additives (Table 1). Three experimental diets contained commercially available products: a blend of organic acids (treatment A), a preparation with organic acids and essential oils (treatment AO) or preparation of herbal extracts (treatment HE). The A preparation containing a blend of formic acid and propionic acid (2.3:1) were applied in the amount $5.0 \mathrm{~g} / \mathrm{kg}$ of feed. The AO preparation, containing a blend of citric acid (12\%), fumaric acid (10\%), orthophosphoric acid (6\%) and malic acid (5\%) with a mixture $(2 \%)$ of hydrogenated essential oils from citrus fruits, cinnamon, oregano and thyme, was applied at the following doses: $1.0 \mathrm{~g} / \mathrm{kg}$ (to 28 days of age), 0.75 $\mathrm{g} / \mathrm{kg}$ (from 29 to 84 days of age) and $0.5 \mathrm{~g} / \mathrm{kg}$ of feed (from 85 day). Diet HE contained a blend of oregano (Origanum vulgare L.) essential oil and spice extracts of turmeric (Curcuma longa L.) and capsicum (Capsicum frutenscens L.), were applied in the amount $0.3 \mathrm{~g} / \mathrm{kg}$ of feed.

All feed mixtures were formulated using least-cost linear programming software to meet the nutrient requirements for turkeys, according to British United Turkeys (B.U.T., 2002) recommendation. The composition and calculated nutritive value of basal mixtures are given in Table 1. Starter mixtures were offered as crumbles and the other diets as $3 \mathrm{~mm}$ pellets. Fresh feed and water were provided daily and were available ad libitum. The ingredients of mixtures were mixed using a horizontal ribbon blade mixer with a capacity of 1,000 $\mathrm{kg}$. Each batch was mixed for a period of $6 \mathrm{~min}$, next put into a conditioner where steam was added at a pressure of $1.5 \mathrm{bar}$, and heated at a set temperature 
Table 1. Composition $(\mathrm{g} / \mathrm{kg})$ and calculated nutrient content of the basal mixtures for turkeys from 1 to 140 days of age

\begin{tabular}{lrrrrr}
\hline Item & Starter 1 & Starter 2 & Grower 1 & Grower 2 & Finisher \\
& 1 to 28 d & 29 to $56 \mathrm{~d}$ & 57 to $84 \mathrm{~d}$ & 85 to 112 d & 113 to 140 d \\
\hline Component & & & & & \\
wheat & 191.2 & 261.5 & 485.8 & 615.3 & 482.7 \\
maize & 250.0 & 250.0 & 100.0 & 100.0 & 100.0 \\
triticale & - & - & - & - & 150.0 \\
potato protein & 50.0 & 25.0 & - & - & - \\
soyabean meal, 46\% of CP & 425.0 & 388.0 & 327.3 & 200.0 & 172.1 \\
soyabean oil & 22.0 & 21.0 & 43.2 & 48.0 & 20.0 \\
animal fat & - & - & - & - & 40.9 \\
limestone & 12.4 & 12.0 & 11.6 & 11.3 & 9.2 \\
monocalcium phosphate & 32.4 & 27.0 & 14.8 & 12.2 & 11.7 \\
salt & 3.1 & 2.8 & 2.6 & 2.6 & 2.6 \\
NaPO ${ }_{4}$ & 1.3 & 1.3 & 1.3 & 1.3 & 0.7 \\
DL-methionine 99 & 3.0 & 2.6 & 2.6 & 0.8 & 1.0 \\
L-lysine 99 MonohydroCL & 3.6 & 3.2 & 4.1 & 3.0 & 3.2 \\
L-threonine & 1.0 & 0.6 & 1.7 & 0.5 & 0.9 \\
vitamin-mineral premix ${ }^{1}$ & 5.0 & 5.0 & 5.0 & 5.0 & 5.0 \\
Calculated nutritive value & & & & & \\
ME, kcal/kg & & & & & \\
CP, \% & 2789 & 2822 & 3000 & 3146 & 3250 \\
Lys, \% & 28.05 & 25.16 & 21.78 & 17.17 & 16.25 \\
Met + Cys, \% & 1.82 & 1.58 & 1.39 & 1.00 & 0.96 \\
Ca, \% & 1.18 & 1.05 & 0.94 & 0.65 & 0.64 \\
available P, \% & 1.34 & 1.20 & 0.90 & 0.80 & 0.70 \\
Na, \% & 0.74 & 0.65 & 0.45 & 0.40 & 0.37 \\
\hline
\end{tabular}

${ }^{1}$ supplied the following per $\mathrm{kg}$ of starter/grower and finisher diet, IU: vit. A (all-trans retinol acetate) 15,000/13,000, cholecalciferol 4.00/3.00, vit. E (all-rac- $\alpha$-tocopherol acetate) 40/35; mg: vit. $\mathrm{K}_{3}$ (menadione nicotinamide bisulfate) $2.5 / 2$, thiamin $2.5 / 2$, riboflavin $10 / 8$, niacin $70 / 65$, vit. $\mathrm{B}_{6} 5 / 3.5$, pantothenic acid $20 / 18$, folic acid $2 / 1.5$, biotin $0.3 / 0.2$, choline chloride $600 / 400$, Mn 120/100, Zn 90/80, Fe 60/50, Cu 10/8, J 1/0.8, Se 0.3/0.3

of $65^{\circ} \mathrm{C}$ for $10-15 \mathrm{sec}$. The temperature was monitored at the conditioner outlet and controlled by a Datastor computerized press controller (with a maximum variation from the set temperature of $\pm 1^{\circ} \mathrm{C}$ ). Pelletized diets were passed through a cooler. Pelleted feed was supplied by the local commercial animal feed mill.

\section{Animals managament}

All managament practices and euthanasia were carried out with full consideration of animal welfare. Poults were vaccinated for turkey rhinotracheitis (TRT) by 
spray application at $1 \mathrm{~d}$ of age and were allocated at random to 16 pens ( 25 turkeys per pen, 100 birds per treatment) with straw as bedding material. Stocking density was approximately $50 \mathrm{~kg} \mathrm{BW} / \mathrm{m}^{2}$ of usable floor space in all pens. Visual health inspection of all birds was performed on a daily basis. Brooder rings for poults (till 10 days of age) and additional heat sources (till 28 days of age) were installed in the pens. Heating was provided by a central heating system and electric heaters (red light). The brooder unit's temperature was set at $35^{\circ} \mathrm{C}$ and then altered as needed to suit bird comfort. Room temperature was set at $28^{\circ} \mathrm{C}$ on the day of placement, and was subsequently reduced by $2^{\circ} \mathrm{C}$ per week. The temperature and humidity were recorded on a daily basis at $8 \mathrm{AM}$ and $3 \mathrm{PM}$. The lighting program in the room was as follows: $23 \mathrm{~h}$ light at about 100 lux till 3 days of age and $14 \mathrm{~h}$ light at 5-6 1x from day 4 until the end of the experiment. Relative humidity was about 65 to $70 \%$. Air changes were $0.4-0.5 \mathrm{~m}^{3} / \mathrm{h} / \mathrm{kg}$ of BW from 2 to 7 weeks of age and $0.7-0.8 \mathrm{~m}^{3} / \mathrm{h} / \mathrm{kg}$ of body weight from 8 weeks of age.

\section{Basic experimental data}

Mortality and the body weights of dead birds were recorded every day. Feed intake per replicate and the body weights of turkeys were recorded on day 28, 56, 84, 112 and 140. Gastrointestinal tract development and metabolism were evaluated after 56 days of feeding. Additionally, carcass characteristics (dressing percentage, abdominal fat and breast, thigh and drumstick muscles) were determined after 140 days of the experiment.

\section{Gastrointestinal tract properties}

After 56 days of experimental feeding, the birds were weighed and 10 turkeys representing the average body weight of each treatment were killed according to the recommendations for euthanasia of experimental animals (Close et al., 1997). Selected parts of the digestive tract (crop, gizzard, ileum, caeca) were removed and weighed. The $\mathrm{pH}$ of these sections was measured with a microelectrode and a pH/ ION meter (Model 301, Hanna Instruments, Vila do Conole, Portugal). Samples of the ileal (from the middle part of the ileum) and caecal contents were weighed and transferred to microfuge tubes, which were immediately stored at $-40^{\circ} \mathrm{C}$ to measure dry matter content, digesta viscosity, short chain fatty acid (SCFA) content and the activity of microbial enzymes. The cecum part was flushed clean with ice-cold saline, blotted on filter paper, and weighed (caecal tissue weight). The same procedure was repeated for the small intestine. Dry matter of the ileal and caecal digesta was determined at $105^{\circ} \mathrm{C}$.

Viscosity measurements of the ileal digesta were determined using a Brookfield cano-plate viscometer (Model LVDV-II+CP40, Brookfield Engineering Lab. 
Inc., Stoughton, MA). Samples of digesta (about $2 \mathrm{~g}$ from the middle part of the ileum between Meckel's diverticulum and ileocaecal junction) were centrifuged $\left(13,000 \mathrm{rpm}, 15 \mathrm{~min}\right.$ at $\left.20^{\circ} \mathrm{C}\right)$ and the supernatant was collected. The viscosity of the supernatant was determined at $37^{\circ} \mathrm{C}$ and with shear rates of $300-600 \mathrm{sec}^{-1}$. The reading was taken after one min.

\section{SCFA concentration and activity of microbial enzymes}

Caecal digesta samples were measured for SCFA concentration by gas chromatography (Shimadzu GC 14A, Shimadzu Co., Kyoto, Japan). The samples (of about $0.2 \mathrm{~g}$ ) were weighed, mixed with $0.2 \mathrm{ml}$ of formic acid, diluted with deionised water, and centrifuged at $10,000 \mathrm{~g}$ for $5 \mathrm{~min}$. The supernatant was loaded onto a chromatography glass column, $2.5 \mathrm{~m} \times 2.6 \mathrm{~mm}$, containing commercial packing: $10 \%$ SP-1200/1\% $\mathrm{H}_{3} \mathrm{PO}_{4}$ on 80/100 Chromosorb W AW (Supelco Co., Bellefonte, $\mathrm{PA})$. The chromatograph was coupled to a flame ionization detector, and we used a column temperature of $110^{\circ} \mathrm{C}$, detector temperature of $180^{\circ} \mathrm{C}$, and injector temperature of $195^{\circ} \mathrm{C}$.

Microbial enzyme activity in the ileal and caecal digesta was measured by the rate of p- or o-nitrophenol release from their nitrophenylglucosides according to the modified method of Djouzi and Andrieux (1997) described by Juśkiewicz et al. (2002). The following substrates (Sigma Chemical Co., St. Louis, MO) were used: for $\beta$-glucuronidase, $\mathrm{p}$-nitrophenyl- $\beta$-D-glucuronide; for $\alpha$-galactosidase, p-nitrophenyl- $\alpha$-D-galactopyranoside; for $\beta$-galactosidase, $p$-nitrophenyl- $\beta$ - $D$ galactopyranoside; for $\alpha$-glucosidase, $p$-nitrophenyl- $\alpha$-D-glucopyranoside; and for $\beta$-glucosidase, $p$-nitrophenyl- $\beta$-D-glucopyranoside. The reaction mixture contained $0.3 \mathrm{ml}$ of a substrate solution $(5 \mathrm{mM}$ ) and $0.2 \mathrm{ml}$ of a 1:10 (vol: vol) dilution of the digesta sample in $100 \mathrm{mM}$ phosphate buffer $(\mathrm{pH} 7.0)$ after centrifugation at $10,000 \mathrm{~g}$ for $15 \mathrm{~min}$. Incubation was carried out at $37^{\circ} \mathrm{C}$, and p-nitrophenol was quantified at $400 \mathrm{~nm}$ and o-nitrophenol at $420 \mathrm{~nm}$ after the addition of $2.5 \mathrm{ml}$ of $0.25 \mathrm{M}$ cold sodium carbonate. The enzymatic activity was expressed as micromoles of product formed per min (IU) per gram of digesta in the ileal and cecal sample.

\section{Statistical analysis}

All data were analysed statistically by a one-way analysis using a general linear model procedure for ANOVA and Duncan's multiple range test. Replicate means served as experimental units for statistical analysis. Treatment effects were considered to be significant at $\mathrm{P} \leq 0.05$ and $\mathrm{P} \leq 0.01$. 


\section{RESULTS}

The effects of feed additives on the performance of turkeys are presented in Table 2. Cumulative viability averaged $94-95 \%$ over the entire experimental period, and was not influenced by the tested feed additives. The applied supplements did not have a clear positive effect on performance of turkeys. At 28 and 56 days of age, the body weight of turkeys fed diets with $\mathrm{A}, \mathrm{AO}$ or HE were higher by $1.9-3.7 \%$ than in the control group, but the effect was statistically non-significant. At 84 days of age, the feed additives significantly (5.6-6.6\%; $\mathrm{P} \leq 0.01)$ improved the body weight of birds. At the end of the experimental period (140 days of age), the body weight of these turkeys were higher by $3.3-3.9 \%$ than in the control treatment, but this difference was statistically non-significant. In comparison with the control group, the feed conversion ratio in the remaining treatments was lower by $1.3-4.0 \%$ (to 56 days of age) and by $2.4-5.3 \%$ (to 140 days of age), but these differences were statistically non-significant. The use of feed additives had no significant effect on the slaughter performance (Table 3 ). Only the proportion of thigh muscles was lower $(\mathrm{P} \leq 0.05)$ in the control turkeys than in those of treatment A.

Table 2. Effect of diets containing organic acids or herbal extract on the body weight (BW), feed conversion ratio (FCR) and mortality of turkeys raised from 1 to 140 days of age ${ }^{1}$

\begin{tabular}{|c|c|c|c|c|c|}
\hline \multirow{2}{*}{ Item } & \multicolumn{4}{|c|}{ Dietary treatment ${ }^{2}$} & \multirow{2}{*}{ SEM } \\
\hline & $\mathrm{C}$ & $\mathrm{A}$ & $\mathrm{AO}$ & $\mathrm{HE}$ & \\
\hline \multicolumn{6}{|l|}{$B W, \mathrm{~kg} / \mathrm{bird}$} \\
\hline at $28 \mathrm{~d}$ & 1.12 & 1.13 & 1.16 & 1.12 & 0.006 \\
\hline at $56 \mathrm{~d}$ & 4.26 & 4.42 & 4.35 & 4.35 & 0.021 \\
\hline at $84 \mathrm{~d}$ & $9.07^{\mathrm{A}}$ & $9.67^{\mathrm{B}}$ & $9.58^{\mathrm{B}}$ & $9.61^{\mathrm{B}}$ & 0.044 \\
\hline at $112 \mathrm{~d}$ & 14.26 & 14.62 & 14.64 & 14.65 & 0.067 \\
\hline at $140 \mathrm{~d}$ & 18.51 & 19.23 & 19.22 & 19.11 & 0.117 \\
\hline \multicolumn{6}{|l|}{$F C R, \mathrm{~kg} / \mathrm{kg}$} \\
\hline 1 to $28 \mathrm{~d}$ & 1.51 & 1.46 & 1.48 & 1.49 & 0.012 \\
\hline 1 to $56 \mathrm{~d}$ & 2.07 & 1.99 & 2.04 & 1.98 & 0.015 \\
\hline 1 to $84 \mathrm{~d}$ & 2.34 & 2.21 & 2.23 & 2.19 & 0.028 \\
\hline 1 to $112 \mathrm{~d}$ & 2.65 & 2.59 & 2.59 & 2.58 & 0.034 \\
\hline 1 to $140 \mathrm{~d}$ & 2.91 & 2.76 & 2.84 & 2.81 & 0.042 \\
\hline \multicolumn{6}{|l|}{ Mortality, \% } \\
\hline 1 to $56 \mathrm{~d}$ & 3.0 & 3.0 & 1.0 & 1.0 & \\
\hline 1 to $140 \mathrm{~d}$ & 5.0 & 6.0 & 5.0 & 6.0 & \\
\hline
\end{tabular}

${ }^{\mathrm{A}-\mathrm{B}}$ means within the same line with no common superscripts differ $(\mathrm{P} \leq 0.01)$

${ }^{1}$ data represent mean values of four replicate pens of 25 turkeys each

${ }^{2}$ experimental diets: $\mathrm{C}=$ basal mixture without any feed additives; $\mathrm{A}=$ basal mixture + organic acids; $\mathrm{AO}=$ basal mixture + preparation with organic acids and essential oils; $\mathrm{HE}=$ basal mixture + preparation with oregano essential oil and spice extracts of turmeric and capsicum 
Table 3. Effect of diets containing organic acids or herbal extract on the carcass characteristic of turkeys at the age of 140 days, $\%$ of body weight ${ }^{1}$

\begin{tabular}{|c|c|c|c|c|c|}
\hline \multirow{2}{*}{ Item } & \multicolumn{4}{|c|}{ Dietary treatment ${ }^{2}$} & \multirow{2}{*}{ SEM } \\
\hline & $\mathrm{C}$ & $\mathrm{A}$ & $\mathrm{AO}$ & $\mathrm{HE}$ & \\
\hline Dressing percentage & 82.04 & 82.78 & 82.42 & 83.02 & 0.175 \\
\hline Breast muscles & 25.01 & 25.15 & 25.13 & 26.08 & 0.249 \\
\hline Thigh muscles & $10.39^{\mathrm{a}}$ & $11.20^{\mathrm{b}}$ & $10.57^{\mathrm{ab}}$ & $10.30^{\mathrm{a}}$ & 0.131 \\
\hline Drumstick muscles & 7.54 & 7.91 & 7.57 & 7.37 & 0.131 \\
\hline Abdominal fat & 0.83 & 1.18 & 1.16 & 1.22 & 0.083 \\
\hline
\end{tabular}

a-b means within the same line with no common superscripts differ $(\mathrm{P} \leq 0.05)$

${ }^{1}$ data represent mean values of 10 turkeys per treatment

${ }^{2}$ as in Table 2

The effects of organic acids (A), organic acids with essential oils (AO) or herbal extract (HE) on the functioning of the upper part of GIT of turkeys are presented in Table 4. Compared to the control treatment (C), diet supplementation with A and $\mathrm{HE}$ significantly $(\mathrm{P} \leq 0.05)$ and with $\mathrm{AO}$ numerically decreased the $\mathrm{pH}$ of the crop contents. The $\mathrm{pH}$ of the ileal digesta in treatment $\mathrm{HE}$ was significantly $(\mathrm{P} \leq 0.05)$ lower than in the control group.

Table 4. Effect of diets containing organic acids or herbal extract on the functioning of the upper part of gastrointestinal tract of turkeys at the age of 56 days ${ }^{1}$

\begin{tabular}{|c|c|c|c|c|c|}
\hline \multirow{2}{*}{ Indices } & \multicolumn{4}{|c|}{ Dietary treatment ${ }^{2}$} & \multirow{2}{*}{ SEM } \\
\hline & $\mathrm{C}$ & A & $\mathrm{AO}$ & $\mathrm{HE}$ & \\
\hline $\mathrm{pH}$ of the crop digesta & $4.97^{\mathrm{a}}$ & $4.64^{b}$ & $4.86^{\mathrm{ab}}$ & $4.61^{\mathrm{b}}$ & 0.054 \\
\hline $\mathrm{pH}$ of the gizzard digesta & 2.79 & 2.92 & 2.62 & 2.96 & 0.087 \\
\hline Gizzard, g/kg of body weight & 5.12 & 4.64 & 4.67 & 5.18 & 0.081 \\
\hline Ileal tissue, $\mathrm{g} / \mathrm{kg}$ of body weight & $25.99^{\mathrm{ab}}$ & $24.18^{\mathrm{b}}$ & $26.73^{\mathrm{a}}$ & $26.69^{\mathrm{a}}$ & 0.424 \\
\hline Ileal digesta, $\mathrm{g} / \mathrm{kg}$ of body weight & $13.06^{\mathrm{a}}$ & $8.90^{\mathrm{b}}$ & $8.09^{\mathrm{b}}$ & $6.21^{\mathrm{b}}$ & 0.589 \\
\hline Dry matter of the ileal digesta, $\%$ & 16.34 & 16.10 & 16.95 & 16.52 & 0.292 \\
\hline $\mathrm{pH}$ of the ileal digesta & $6.27^{\mathrm{a}}$ & $6.05^{\mathrm{ab}}$ & $6.14^{\mathrm{ab}}$ & $5.91^{\mathrm{b}}$ & 0.057 \\
\hline Viscosity of the ileal digesta, $\mathrm{m} \cdot$ Pas & $2.40^{\mathrm{a}}$ & $2.22^{\mathrm{ab}}$ & $2.09^{\mathrm{ab}}$ & $2.00^{\mathrm{b}}$ & 0.080 \\
\hline \multicolumn{6}{|c|}{ Enzyme activity, U/g of the ileal digesta } \\
\hline$\alpha$-glucosidase & $0.16^{\mathrm{b}}$ & $0.44^{\mathrm{a}}$ & $0.21^{\mathrm{b}}$ & $0.53^{\mathrm{a}}$ & 0.037 \\
\hline$\beta$-glucosidase & $>0.01$ & $>0.01$ & $>0.01$ & $>0.01$ & 0.002 \\
\hline$\alpha$-galactosidase & 0.03 & 0.04 & 0.06 & 0.07 & 0.010 \\
\hline$\beta$-galactosidase & $0.06^{\mathrm{ab}}$ & $0.05^{\mathrm{ab}}$ & $0.01^{\mathrm{b}}$ & $0.07^{\mathrm{a}}$ & 0.011 \\
\hline$\beta$-glucuronidase & 0.03 & 0.03 & 0.02 & 0.04 & 0.005 \\
\hline
\end{tabular}

${ }^{\mathrm{a}-\mathrm{b}}$ means within the same line with no common superscripts $\operatorname{differ}(\mathrm{P} \leq 0.05)$

${ }^{1}$ data represent mean values of 10 turkeys per treatment

${ }^{2}$ as in Table 2 
The ileal tissue weight in turkeys fed diets with $\mathrm{AO}$ or HE was by $10 \%(\mathrm{P} \leq 0.05)$ higher than in treatment $\mathrm{A}$. The weight of the ileal digesta of turkeys of the control group (C) was significantly higher, compared to all other treatments (13.1 vs 6.2$8.9 \mathrm{~g} / \mathrm{kg}$ of BW). It corresponded with higher viscosity in the control group than in turkeys fed diets with A, AO or HE supplementation. Dry matter concentration in the ileal digesta were unaffected by the treatments.

Microbial glycolytic enzyme activity in the ileal digesta was relatively low. Compared to the control treatment, dietary supplementation with A or HE significantly increased $(\mathrm{P} \leq 0.05)$ the activity of $\alpha$-glucosidase in the ileal digesta.

The caecal tissue weight and the weight of the caecal digesta in turkeys (Table 5) fed diets with A, AO or HE supplementation were numerically higher than in the control treatment $(\mathrm{C})$, but the effect was statistically non-significant.

Table 5. Effect of diets containing organic acids or herbal extract on the functioning of the caeca of turkeys at the age of 56 days $^{1}$

\begin{tabular}{|c|c|c|c|c|c|}
\hline \multirow{2}{*}{ Indices } & \multicolumn{4}{|c|}{ Dietary treatment $^{2}$} & \multirow{2}{*}{ SEM } \\
\hline & $\mathrm{C}$ & A & $\mathrm{AO}$ & $\mathrm{HE}$ & \\
\hline Caecal tissue, $\mathrm{g} / \mathrm{kg}$ of body weight & 4.14 & 4.31 & 4.29 & 4.41 & 0.075 \\
\hline Caecal digesta, $\mathrm{g} / \mathrm{kg}$ of body weight & 2.84 & 3.58 & 3.36 & 3.02 & 0.186 \\
\hline Dry matter of the caecal digesta, $\%$ & 19.20 & 18.61 & 17.21 & 17.74 & 0.480 \\
\hline $\mathrm{pH}$ of the caecal digesta & 5.78 & 6.08 & 6.00 & 5.91 & 0.053 \\
\hline \multicolumn{6}{|c|}{ Enzyme activity, U/g of the caecal digesta } \\
\hline$\alpha$-glucosidase & $1.24^{\mathrm{b}}$ & $1.97^{\mathrm{a}}$ & $1.79^{\mathrm{a}}$ & $1.62^{\mathrm{ab}}$ & 0.088 \\
\hline$\beta$-glucosidase & $0.23^{\mathrm{ab}}$ & $0.33^{\mathrm{a}}$ & $0.23^{\mathrm{ab}}$ & $0.16^{\mathrm{b}}$ & 0.026 \\
\hline$\alpha$-galactosidase & $0.98^{\mathrm{b}}$ & $2.41^{\mathrm{a}}$ & $2.67^{\mathrm{a}}$ & $1.07^{\mathrm{b}}$ & 0.211 \\
\hline$\beta$-galactosidase & $2.34^{\mathrm{bc}}$ & $3.99^{\mathrm{ab}}$ & $4.20^{\mathrm{a}}$ & $2.16^{\mathrm{c}}$ & 0.324 \\
\hline$\beta$-glucuronidase & $1.14^{\mathrm{b}}$ & $2.51^{\mathrm{a}}$ & $1.50^{\mathrm{b}}$ & $0.89^{\mathrm{b}}$ & 0.160 \\
\hline \multicolumn{6}{|c|}{$S C F A^{3}$ concentration, $\mu \mathrm{mol} / \mathrm{g}$ of the caecal digesta } \\
\hline acetate & 32.8 & 34.0 & 32.5 & 33.3 & 0.927 \\
\hline propionate & 20.8 & 20.3 & 18.1 & 22.1 & 0.770 \\
\hline iso-butyrate & 0.36 & 0.52 & 0.27 & 0.52 & 0.055 \\
\hline butyrate & 20.6 & 19.4 & 21.0 & 19.6 & 0.617 \\
\hline iso-valerate & 0.60 & 0.78 & 0.49 & 0.67 & 0.051 \\
\hline valerate & $2.66^{\mathrm{a}}$ & $2.24^{\mathrm{ab}}$ & $1.45^{\mathrm{b}}$ & $1.82^{\mathrm{ab}}$ & 0.175 \\
\hline Total SCFA & 77.8 & 77.2 & 73.9 & 78.0 & 1.579 \\
\hline SCFA pool, $\mu \mathrm{mol} / \mathrm{kg}$ of body weight & 220.8 & 273.0 & 252.8 & 231.77 & 14.33 \\
\hline \multicolumn{6}{|l|}{ SCFA profile, $\mu \mathrm{mol} / 100 \mu \mathrm{mol}$} \\
\hline acetate & 42 & 44 & 44 & 43 & 0.715 \\
\hline propionate & 27 & 26 & 25 & 29 & 0.879 \\
\hline butyrate & 27 & 25 & 29 & 25 & 0.695 \\
\hline
\end{tabular}


On the other hand, the DM content of the digesta in these treatments was by 3.1$10.4 \%$ lower than in the control group (no statistically significant differences). The addition of $\mathrm{A}, \mathrm{AO}$ or HE had no effect on the $\mathrm{pH}$ of the caecal digesta.

In the caeca, the highest activity of $\alpha$-glucosidase and $\alpha$-galactosidase was recorded in treatments A or AO. Compared with treatment HE, significantly $(\mathrm{P} \leq 0.05)$ higher activity of $\beta$-glucosidase in treatment $\mathrm{A}$, as well as higher activity of $\beta$-galactosidase in treatments $\mathrm{A}$ and $\mathrm{AO}$, were found. The dietary supplementation of formic and propionic acid (treatment $\mathrm{A}$ ) significantly increased $(\mathrm{P} \leq 0.05)$ the activity of potentially detrimental $\beta$-glucuronidase in the caeca.

After 56 days of experimental feeding, no influence of feed additives on the total production of short-chain fatty acids in the caecal digesta (SCFA pool) was observed. Significant differences $(\mathrm{P} \leq 0.05)$ were noted in valerate acid concentration only in the case of treatments $\mathrm{C}$ and $\mathrm{AO}$, but this acid does not make up the essential part of the SCFA pool. At the same time, the proportions of major fatty acids (acetate, propionate and butyrate) were similar. Statistically nonsignificant increase in butyrate acid proportion, as compared to the proportion of acetic acid and propionic acid, was observed in turkeys fed diets with AO.

\section{DISCUSSION}

Like antibiotics, short-chain organic acids have a specific antimicrobial activity, particularly effective against acid-intolerant species (E. coli, Salmonella and Campylobacter). Organic acids have also several additional effects. These include reduction in digesta $\mathrm{pH}$, increased pancreatic secretion, and trophic effects on the gastrointestinal mucosa. Organic acids have a clear and significant benefit in weanling piglets. The data on the use of organic acids or natural feed additives as alternatives to antibiotic growth promoters in poultry diets (mainly in diets for broilers and turkeys), published to date, are, however, inconsistent. Lack of consistency in demonstrating an organic acid benefit is related to uncontrolled variables such as buffering capacity of dietary ingredients, presence of other antimicrobial compounds, cleanliness of the production environment, and heterogeneity of gut microbiota. A reduction in caecal $\mathrm{pH}$ of broiler chickens was observed when a blend of formic acid/propionic acid was added at $1.0 \%$ of feed (Waldroup et al., 1995). However in other studies the application 5 and $10 \mathrm{~g} / \mathrm{kg}$ feed of formic acid (Hernandez et al., 2006) or buffered propionic acid (Izat et al., 1990) had no effect on intestinal pH in broiler chickens. Similarly, acidified water containing a commercial organic acid product at $\mathrm{pH} 4.0$ had no significant influence on the $\mathrm{pH}$ and SCFA concentrations in the crop and caecal contents of broilers (Chaveerach et al., 2004). The inclusion of formic and propionic acids to the feed of hens made no difference to the $\mathrm{pH}$ of the intestinal 
tract, but resulted in higher concentrations of these acids in the contents of the crop and gizzard (Thompson and Hinton, 1997). As reported by Canibe et al. (2001) the antibacterial effect of dietary organic acids in broiler chickens is believed to occur mainly in the upper part of the digestive tract, such as crop and gizzard, where $\mathrm{pH}$ is more appropriate for the action of these acids.

The present study was conducted to investigate the effect of organic acids or herbal extract on male turkeys fed an optimal diet. The application of organic acids in the amount of $5.0 \mathrm{~g} / \mathrm{kg}$ diet (treatment $\mathrm{A}$ ) decreased the $\mathrm{pH}$ of the crop digesta, but had no effect on $\mathrm{pH}$ levels in other segments of GIT. In comparison with the control treatment, the addition of organic acids decreased the viscosity and amount of the ileal digesta, as well as increased the activity of microbial enzymes (including $\beta$-glucuronidase) in the caecal digesta, with no increase in SCFA production. Bacterial $\beta$-glucuronidase in the hindgut is able to release carcinogens from hepatically derived glucuronic acid conjugates (Reddy et al., 1992). In treatment AO, the application of a blend of organic acids with essential oils resulted in a lower amount of the ileal digesta and in higher activity of $\alpha$-glucosidase and $\alpha$ - and $\beta$-galactosidase in the caecal contents, compared to the control group.

In poultry the body weight gain and FCR following the dietary addition of organic acids are not as convincing as the results from pig production. The present study showed that the body weight of turkeys fed diets with organic acids (treatments A and AO) increased, but only to 84 days of age. On day 140 the body weight of turkeys fed diets with organic acids were higher (by 3.9\%) and feed conversion ratio was lower (by 2.4-5.3\%) compared to the control group, but these differences were found to be statistically non-significant. In other studies the application of buffered propionic acid (Izat et al., 1990), 5 and $10 \mathrm{~g} / \mathrm{kg}$ feed of formic acid (Hernandez et al., 2006) or commercial organic acid product at pH 4.0 (Chaveerach et. al., 2004) had also no significant effect on the growth performance of broiler chickens.

In our experiment the essential oil preparation (treatment HE) caused a decrease in the $\mathrm{pH}$ level of the crop and ileal digesta as well as an increase in the activity of $\alpha$-glucosidase in the ileal digesta, but no increase was recorded in microbial enzyme activity and SCFA production in the caecal digesta. Mitsch et al. (2004) suggested that specific blends of essential oils rich in thymol or carvacrol have an antibacterial effect in vitro and affect the stimulation of digestive enzymes, stabilization of intestinal microflora and a reduction of possibly toxic bacterial metabolites, and thus may control the proliferation of $C$. perfringens in broiler intestine. On the other hand, Jamroz et al. (2006) suggest villirelated protective properties of the use of the carvacrol, cinnamaldehyde and capsaicin mixture. The beneficial effect on the protection of intestinal villi through intercellular antioxidant activity may positively affect the absorption of digested nutrients (Manzanillo et al., 2001). 
Essential oil rich in carvacrol (applied alone or in combinations) is known to have a growth-stimulating effect in piglets (Manzanillo et al., 2001) or broiler chickens (Jamroz et al., 2003). In contrast, many authors reported no influence of carvacrol, thymol, oregano essential oil or commercial products with oregano or dried oregano leaves on the performance of broiler chickens and turkeys (Lee et al., 2003; Bampidis et al., 2005; Westendarp et al., 2006). In the present study the body weight of turkeys fed diet with carvacrol-based essential oil (HE treatment) increased, but only to 84 days of age. After 140 days of feeding, the final body weight of turkeys were only slightly higher $(\mathrm{P}>0.05)$ and feed conversion ratio was numerically lower $(\mathrm{P}>0.05)$ in this treatment than in birds fed a non-supplemented diet. The lack of a growth-promoting effect of herbal mixture supplements in these studies may be related to diet composition and environmental conditions. No effect of oregano on growth performance is seen when feeding a well-balanced diet and keeping the birds in a clean environment (Lee et al., 2003), but this does not rule out the possibility that positive effects would have been observed under worse hygienic environmental conditions or when using a less digestible diet.

Our results and the findings of other authors (Bampidis et al., 2005; Westendarp et al., 2006) show that the carcass traits were not influenced by feed supplements containing herbs or essential oils. In our study the only exception was the proportion of thigh muscles in birds from treatment A. However, in an experiment by Izat et al. (1990) dietary supplementation with buffered propionic acid significantly increased the carcass dressing percentage of chickens.

\section{CONCLUSIONS}

In conclusion, the results of our study indicate that when using turkeys under conditions of good hygiene and fed optimal diet, dietary supplementation with organic acids, essential oils or a combination of organic acids and essential oils did not have a clear positive effect on performance and carcass traits, however, there was a slight positive effect on gastrointestinal tract metabolism. The tested supplements caused a decrease in the $\mathrm{pH}$ of the crop digesta and in ileal digesta viscosity as well as an increase in the activity of bacterial enzymes in the caeca, but had no effect on SCFA production. All supplements increased the body weight of turkeys, but only to 84 days of age. The final body weights (at 140 days of age) of turkeys fed diets with the tested supplements were higher by 3.3-3.9\%, and feed conversion ratio decreased by $2.4-5.3 \%$ (statistically non-significantly) in these treatments, compared to the control. 


\section{REFERENCES}

Adam K., Sivropoulou A., Kokkini S., Lanaras T., Arsenakis M., 1998. Antifungal activities of Origanum vulgare subsp. hirtum, Mentha spicata, Lavandula angustifolia, and Salvia fruticosa essential oils against human pathogenic fungi. J. Agr. Food Chem. 46, 1739-1745

Bampidis V.A., Christodoulou V., Florou-Paneri P., Christaki E., Chatzopoulou P.S., Tsiligianni T., Spais A.B., 2005. Effect of dietary dried oregano leaves on growth performance, carcass characteristics and serum cholesterol of female early maturing turkeys. Brit. Poultry Sci. 46, 595-601

B.U.T. Commercial Performance Goals, 2002. British United Turkeys. $5^{\text {th }}$ Edition (England)

Canibe N., Engberg R.M., Jenses B.B., 2002. An overview of the effect of organic acids on gut flora and gut health. Danish Institute of Agricultural Science, Research Centre Foulum (Denmark). http:/ www-afac.slu.se/Workshop\%20Norge/organic_acids_canibe_et_al.pdf. Accessed Jan, 2007

Chaveerach P., Keuzenkamp D.A., Lipman L.J.A., Van Knapen F., 2004. Effect of organic acids in drinking water for young broilers on Campylobacter infection, volatile fatty acid production, gut microflora and histological cell changes. Poultry Sci. 83, 330-334

Close B., Banister K., Baumans V., Bernoth E.M., Bromage N., Bunyan J., Erhardt W., Flecknell P., Gregory N., Hackbarth H., Morton D., Warwick C., 1997. Recommendations for euthanasia of experimental animals. Part 2. Lab. Anim. 31, 1-32

Faleiro L., Miguel G., Gomes S., Costa L., Venancio Teixeira F., Figueiredo A., Barroso A.C., Pedro J.G., 2005. Antibacterial and antioxidant activities of essential oils isolated from Thymbra capitata L. (Cav.) and Origanum vulgare L. J. Agr. Food Chem. 53, 8162-8168

Hazzit M., Baaliouamer A., Faleiro M.L., Miguel M.G., 2006. Composition of the essential oils of Thymus and Origanum species from Algeria and their antioxidant and antimicrobial activities. J. Agr. Food Chem. 54, 6314-6321

Hernández F., García V., Madrid J., Orengo J., Catalá P., Megías M.D., 2006. Effect of formic acid on performance, digestibility, intestinal histomorphology and plasma metabolite levels of broiler chickens. Brit. Poultry Sci. 47, 50-56

Immerseel Van F., Boyen F., Gantois I., Timbermont L., Bohez L., Pasmans F., Haesebrouck F., Ducatelle R., 2005. Supplementation of coated butyric acid in the feed reduces colonization and shedding of Salmonella in poultry. Poultry Sci. 84, 1851-1856

Izat A.L., Tidwell N.M., Thomas R.A., Reiber M.A., Adams M.H., Colberg M., Waldroup P.W., 1990. Effects of a buffered propionic acid in diets on the performance of broiler chickens and on microflora of the intestine and carcass. Poultry Sci. 69, 818-826

Jamroz D., Orda J., Kamel C., Wiliczkiewicz A., Wertelecki T., Skorupińska J., 2003. The influence of phytogenic extract on performance, nutrients digestibility, carcass characteristic and gut microbial status in broiler chickens. J. Anim. Feed Sci. 12, 583-596

Jamroz D., Wertelecki T., Houszka M., Kamel C., 2006. Influence of diet type on the inclusion of plant origin active substances on morphological and histochemical characteristics of the stomach and jejunum walls in chicken. J. Anim. Physiol. Anim. Nutr. 90, 255-268

Juśkiewicz J., Zduńczyk Z., Wróblewska M., Oszmiański J., Hernandez T., 2002. The response of rats to feeding with diets containing grapefruit flavonoid extract. Food Res. Int. 35, 201-205

Lee K.W., Everts H., Kappert H.J., Frehner M., Losa R., Beynen A.C., 2003. Effects of dietary essential oil components on growth performance, digestive enzymes and lipid metabolism in female broiler chickens. Brit. Poultry Sci. 44, 450-457

Manzanillo E.G., Baucells F., Kamel C., Morales J., Perezand J.F., Gasa J., 2001. Effects of plant extracts on the performance and lower gut microflora of early weaned piglets. J. Anim. Sci. Suppl. 1, 473 (Abstr.) 


\section{DIETARY ORGANIC ACIDS OR PLANT EXTRACTS FOR TURKEYS}

Mitsch P., Zitterl-Eglseer K., Kohler B., Gabler C., Losa R., Zimpernik I., 2004. The effect of two different blends of essential oil components on the proliferation of Clostridium perfringens in the intestines of broiler chickens. Poultry Sci. 83, 669-675

Nevas M., Korhonen A.R., Lindstrom M., Turkki P., Korkeala H., 2004. Antibacterial efficiency of finnish spice essential oils against pathogenic and spoilage bacteria. J. Food. Prot. 67, 199-202

Patten J.D., Waldroup P.W., 1988. Use of organic acids in broiler diets. Poultry Sci. 6, 1178-1182

Platel K., Srinivasan K., 2001. A study of the digestive stimulant action of select spices in experimental rats. J. Food Sci. Tech. 38, 358-361

Reddy B.S., Engle A., Simi B., Goldman M., 1992. Effect of dietary fiber on colonic bacterial enzymes and bile acids in relation to colon cancer. Gastroenterology 102, 1475-1482

Roy R.D., Edens F.W., Parkhurst C.R., Qureshi M.A., Havenstein G.B., 2002. Influence of a propionic acid feed additive on performance of turkey poults with experimentally induced poult enteritis and mortality syndrome. Poultry Sci. 81, 951-957

Thompson J.L., Hinton M., 1997. Antibacterial activity of formic and propionic acids in the diet of hens on Salmonellas in the crop. Brit. Poultry Sci. 38, 59-65

Waldroup A., Kaniawato S., Mauromoustakos A., 1995. Performance characteristics and microbiological aspects of broiler fed diets supplemented with organic acids. J. Food Prot. 58, 482-489

Westendarp H., Klaus P., Halle I., Morlein D., Henning M., Kohler P., 2006. Effect of carvacrol, $\gamma$ terpinene and p-cymene-7-ol in broiler feed on growth traits and $\mathrm{N}$-metabolism. Landbauforsch. Volkenrode 56, 149-157 